\title{
Phase transformation involved in the reduction process of magnesium oxide in calcined dolomite by ferrosilicon with additive of aluminum
}

https://doi.org/10.1515/gps-2020-0017

Received July 22, 2019; accepted December 09, 2019.

Abstract: Metal magnesium is mainly produced from the calcined dolomite by the silicothermic production. However, in this process, the reduction temperature is higher while the reaction speed is slow, which results in higher energy consumption and serious environmental problems. In this paper, adding aluminum into the ferrosilicon reducing agent is expected to lower the reaction temperature so as to solve the problems above. The phase transition involved in the whole reduction process including with and without aluminum addition were investigated in details by theoretical calculation and experimental research. The influence of aluminum on the magnesium oxide reduction path was analysis to clarify the internal mechanism. The results show that aluminum added into the ferrosilicon would first react with magnesium oxide to form magnesium vapor and alumina under vacuum pressure of $10 \mathrm{~Pa}$ when the temperature rises to $720^{\circ} \mathrm{C}$. Then, calcium aluminate would be formed by the reaction of aluminum oxide and calcium oxide. Once the temperature reaches $1150^{\circ} \mathrm{C}$, silicon begins to reduce the magnesium oxide to create the silicon oxide that will finally react with calcium oxide to form calcium silicate. When the temperature rises above $1150^{\circ} \mathrm{C}$, both the aluminum and silicon will participate in the reduction of magnesium oxide. In the process of heating up, the mixture of aluminum, ferrosilicon and calcined dolomite forms $\mathrm{Mg}_{2} \mathrm{Al}_{4} \mathrm{Si}_{5} \mathrm{O}_{18}$ and $\mathrm{Ca}_{3} \mathrm{Al}_{2}(\mathrm{OH})_{12}$ phase with the components in calcined dolomite. $\mathrm{Mg}_{2} \mathrm{Al}_{4} \mathrm{Si}_{5} \mathrm{O}_{18}$ and $\mathrm{Ca}_{3} \mathrm{Al}_{2}(\mathrm{OH})_{12}$ phase finally form $\mathrm{Ca}_{12} \mathrm{Al}_{14} \mathrm{O}_{33}$ phase. The interaction between aluminum and ferrosilicon in

\footnotetext{
* Corresponding author: Yaoning Wang, School of Metallurgical Engineering, Xi'an University of Architecture and Technology, 710055 Xi'an, China; Key Laboratory of gold and Resources of Shaanxi Province, 710055 Xi'an, China email: yaoningwang@126.com Hongzhou Ma, Zhixian Wang and Dingding Wang, School of Metallurgical Engineering, Xi'an University of Architecture and Technology, 710055 Xi'an, China; Key Laboratory of gold and Resources of Shaanxi Province, 710055 Xi'an, China
}

the mixture is less; the mixture of aluminum and ferrosilicon first forms $\mathrm{Al}_{3} \mathrm{FeSi}_{2}$ phase, and finally has the trend of forming $\mathrm{Al}_{4.5} \mathrm{FeSi}$ phase. There is a great difference between the phase transformation of aluminum in the mixture of aluminum, ferrosilicon and calcined dolomite and that of aluminum in the mixture of aluminum and ferrosilicon.

Keywords: aluminum; magnesium; thermal reduction

\section{Introduction}

Currently, the silicothermic is the main method for the extraction of magnesium from the calcined dolomite, and the reduction process mainly uses $\mathrm{FeSi}$ as the reducing agent to reduce $\mathrm{MgO}$ under vacuum conditions at $1200^{\circ} \mathrm{C}$ [1]. Although the cost of ferrosilicon as reductant is lower, the reduction temperature is higher while the reaction speed is slow [2-4] , leading to high energy consumption as well as serious environment problems in reduction process [5]. With the improvement of environmental protection requirements, how to lower the energy consumption is one of the problems that the magnesium smelting industry needs to solve. There are some influence factors involved in this problem such as reduction temperature, reduction reaction rate, and the diffusion rate of magnesium vapor during the reduction process. The silicon in ferrosilicon first reacts with magnesium oxide to form $\mathrm{SiO}_{2}$ that will further combines with $\mathrm{CaO}$ in calcined dolomite to form calcium silicate [6,7]. The high initial reaction temperature of silicon-reduced magnesium oxide leads to high heating temperature. Ferrosilicon has a higher melting point and the solid-solid reaction process leads to slower reduction reaction rate $[8,9]$. The diffusion rate of magnesium vapor is mainly affected by the void ratio in the agglomerate. If the void ratio of the reduced product is large, the porosity of the agglomerate will increase.

Based on the analysis above, searching for a reducing agent with lower reduction temperature and faster reduction rate than ferrosilicon is an alternative way to 
solve this problem. $\mathrm{Al}$ and $\mathrm{Al}(46.7 \%)-\mathrm{Si}(45.7 \%)-\mathrm{Fe}(7.6 \%)$ alloy were considered as a promising substitute materials for FeSi [10-14]. The previous research results showed that these reduction agents can decrease the reduction temperature. The mechanism of magnesium oxide reduction by aluminum and $\mathrm{Al}-\mathrm{Si}-\mathrm{Fe}$ alloy is different from that of ferrosilicon. The initial reaction temperature of aluminum and magnesium oxide is lower. The reason is that aluminum and $\mathrm{Al}-\mathrm{Si}$-Fe have a low melting point and a solid-liquid reaction occurs during reduction. The phase change in the reducing process of magnesium oxide by aluminum goes through three stages. These are the formation of $\mathrm{MgAl}_{2} \mathrm{O}_{4}$, and $\mathrm{Ca}_{12} \mathrm{Al}_{14} \mathrm{O}_{33}$ phases, and the phase transformation from $\mathrm{MgAl}_{2} \mathrm{O}_{4}$ and $\mathrm{Ca}_{12} \mathrm{Al}_{7}$ to $\mathrm{CaAl}_{2} \mathrm{O}_{4}[10]$. Although the reduction process of magnesium oxide by $\mathrm{Al}$ and $\mathrm{Al}-\mathrm{Si}-\mathrm{Fe}$ alloy have many advantages, the higher price of these reducing agents makes it difficult to be industrialized.

With the increasing use of aluminum and its alloy materials, more scrap aluminum and its alloy was inevitably produced. Using these scraps aluminum and its alloy as a reducing agent for magnesium oxide is expected to reduce the cost of magnesium reduction. From the current price of waste aluminum and its alloy, it is still high cost to replace ferrosilicon completely with waste aluminum and its alloy. However, it is expected to reduce the cost of reducing magnesium oxide by using aluminum as the additive of ferrosilicon and replacing part of ferrosilicon as the reducing agent. Because there are many kinds of aluminum and its alloys, it is difficult to study them one by one. Therefore, this study focuses on the behavior of aluminum and ferrosilicon in the reduction process of magnesium oxide. Therefore, in this paper, the phase transition of aluminum and ferrosilicon in the reduction process of $\mathrm{MgO}$ and the phase transition of the mixture of aluminum and ferrosilicon in the heating process were investigated in details.

\section{Theoretical researches}

The main phases of calcined dolomite are $\mathrm{MgO}$ and $\mathrm{CaO}$. When the mixture of aluminum powder and ferrosilicon powder was used as the reductant, the reduction reaction process of calcined dolomite are as follows:

$$
\begin{gathered}
2 \mathrm{MgO}+\mathrm{Si}=2 \mathrm{Mg}_{(\mathrm{g})}+\mathrm{SiO}_{2} \\
3 \mathrm{MgO}+2 \mathrm{Al}_{(\mathrm{l})}=3 \mathrm{Mg}_{(\mathrm{g})}+\mathrm{Al}_{2} \mathrm{O}_{3} \\
1.5 \mathrm{MgO} \cdot \mathrm{Al}_{2} \mathrm{O}_{3}+\mathrm{Al}_{(\mathrm{l})}=1.5 \mathrm{Mg}_{(\mathrm{g})}+2 \mathrm{Al}_{2} \mathrm{O}_{3} \\
\mathrm{SiO}_{2}+\mathrm{Al}_{2} \mathrm{O}_{3}+\mathrm{CaO}=\mathrm{CaO} \cdot \mathrm{Al}_{2} \mathrm{O}_{3} \cdot \mathrm{SiO}_{2}
\end{gathered}
$$

$$
\begin{gathered}
2 \mathrm{MgO} \cdot \mathrm{Al}_{2} \mathrm{O}_{3}+\mathrm{Si}=2 \mathrm{Mg}_{(\mathrm{g})}+2 \mathrm{Al}_{2} \mathrm{O}_{3}+\mathrm{SiO}_{2} \\
\mathrm{MgO} \cdot \mathrm{Al}_{2} \mathrm{O}_{3}+\mathrm{CaO}=\mathrm{MgO}+\mathrm{CaO} \cdot \mathrm{Al}_{2} \mathrm{O}_{3} \\
2 \mathrm{CaO}+\mathrm{SiO}_{2}=2 \mathrm{CaO} \cdot \mathrm{SiO}_{2} \\
\mathrm{CaO}+\mathrm{Al}_{2} \mathrm{O}_{3}=\mathrm{CaO} \cdot \mathrm{Al}_{2} \mathrm{O}_{3} \\
\mathrm{MgO}+\mathrm{Al}_{2} \mathrm{O}_{3}=\mathrm{MgO} \cdot \mathrm{Al}_{2} \mathrm{O}_{3}
\end{gathered}
$$

The database, as implemented in HSC chemistry software 6.0, was used to calculate the $\Delta \mathrm{G}$-T relationship of each reaction at a vacuum of $10 \mathrm{~Pa}$. The initial calculated temperature is higher by $50^{\circ} \mathrm{C}$ than the melting point of aluminum. The equilibrium vapor pressure of magnesium $\left(\mathrm{P}_{M g}\right)$ is roughly equal to the residual pressure of the system. The calculation method of Gibbs free energy under vacuum conditions is shown in Eq. 12 and 13. The relationship between Gibbs free energy of each reaction and temperature under vacuum conditions is shown in Figure 1.

$$
\Delta \mathrm{G}=\Delta \mathrm{G}_{T}+\mathrm{RT} \ln \mathrm{K}
$$

Reduction of magnesium oxide by Aluminum:

$$
\mathrm{K}=\left(\frac{P_{M g}}{P_{0}}\right)^{3}
$$

Reduction of magnesium oxide by Ferrosilicon:

$$
\mathrm{K}=\left(\frac{P_{M g}}{P_{0}}\right)^{2}
$$

where:

$\Delta \mathrm{G}$ - the Gibbs free energy at partial pressure in the system at $10 \mathrm{~Pa}$,

$\Delta \mathrm{G}_{T}$ - the Gibbs free energy at normal pressure,

$P_{M g}$ - the magnesium vapor partial pressure,

$P_{0}$ - atmospheric pressure that is $101325 \mathrm{~Pa}$.

In Figure 1, the Gibbs free energy of reactions 1, 2, 3 and 5 decreases sharply with the increase of temperature at a vacuum of $10 \mathrm{~Pa}$. Other reactions can be performed spontaneously, such as reactions 4, 6, 7, 8 and 9. The initial reduction temperature of magnesium oxide in calcined dolomite by aluminum is about $720^{\circ} \mathrm{C}$ (Eq. 2) while that temperature reduced by silicon is around $1150^{\circ} \mathrm{C}$ (Eq. 1). The magnesium oxide in magnesium aluminate can be reduced by aluminum at $910^{\circ} \mathrm{C}$ (Eq. 3), but as for the silicon used as reducing agents to reduce magnesium aluminate, it need to heat to the temperature of about $1400^{\circ} \mathrm{C} \mathrm{(Eq.} \mathrm{5).}$

When aluminum participates alone in the reduction of magnesium oxide in calcined dolomite, the reduction 


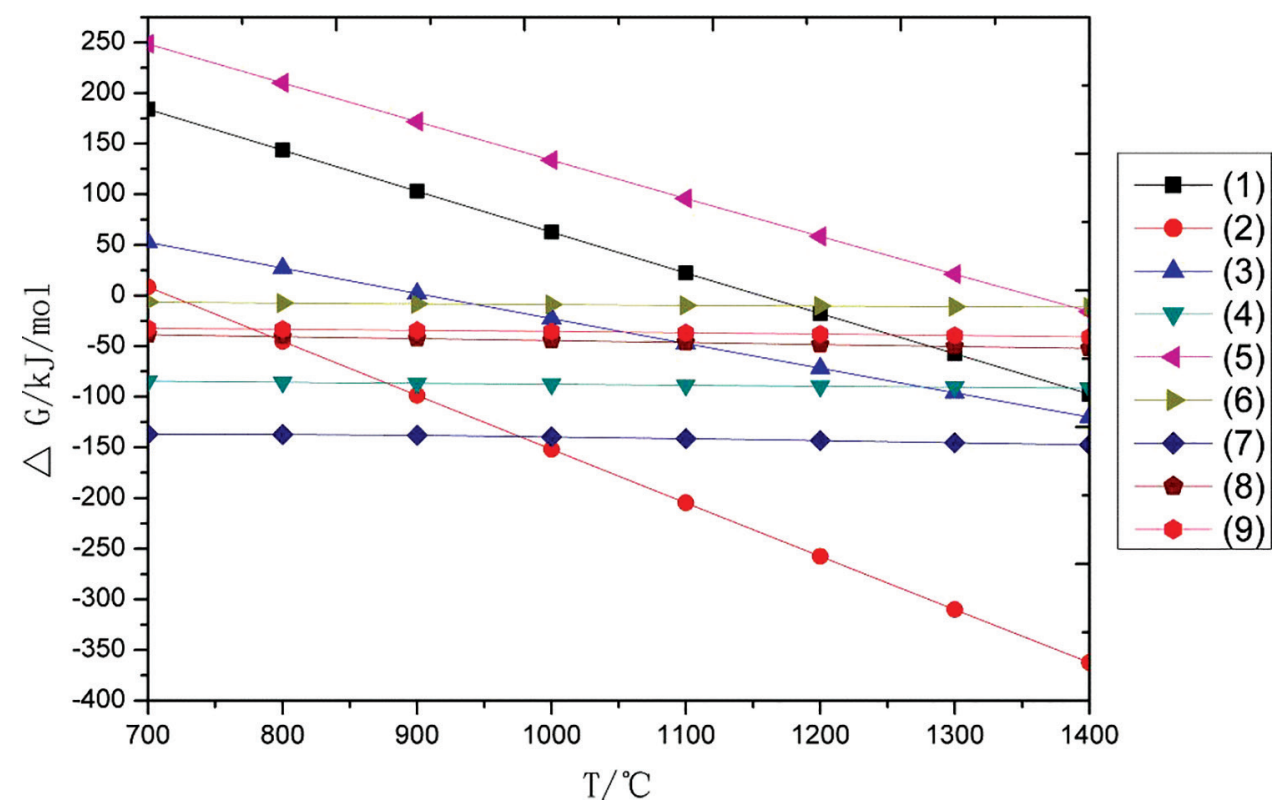

Figure 1: The relationship between Gibbs free energy of each reaction and temperature under vacuum conditions.

reaction occurs at $720^{\circ} \mathrm{C}$, and at the same time, the alumina formed by aluminum reduction of magnesium oxide reacts with the magnesia oxide to form $\mathrm{MgO} \cdot \mathrm{Al}_{2} \mathrm{O}_{3}$. As the heating temperature is above $910^{\circ} \mathrm{C}$, aluminum not only reduces the magnesium oxide in the calcined dolomite, but also begins to reduce the magnesium in the magnesium aluminate. However, when ferrosilicon participates alone in the reduction of magnesium oxide in calcined dolomite, the reduction reaction occurs at $1150^{\circ} \mathrm{C}$, and the silica formed by ferrosilicon reduction of magnesium oxide reacts with the calcium oxide in the calcined dolomite to form $2 \mathrm{CaO} \cdot \mathrm{SiO}_{2}$. When aluminum and ferrosilicon are both involved in the reduction of magnesium oxide, the reaction of aluminum to reduce magnesium oxide above $720^{\circ} \mathrm{C}$, as the temperature is above $910^{\circ} \mathrm{C}$, aluminum not only reduces the magnesium oxide in the calcined dolomite, but also begins to reduce the magnesium in the magnesium aluminate. When the heating temperature is higher than $1150^{\circ} \mathrm{C}$, ferrosilicon participates in the reduction reaction, but ferrosilicon cannot reduce magnesium aluminate.

\section{Experimental}

\subsection{Materials}

Calcined dolomite is taken from Fugu County, Shaanxi Province in China. The main constituents of calcined
Table 1: Chemical analysis of calcined dolomite.

\begin{tabular}{lccccccc}
\hline Phase & $\mathrm{CaO}$ & $\mathrm{MgO}$ & $\mathrm{Fe}_{2} \mathrm{O}_{3}$ & $\mathrm{SiO}_{2}$ & $\mathrm{Al}_{2} \mathrm{O}_{3}$ & $\mathrm{Na}_{2} \mathrm{O}$ & $\mathrm{K}_{2} \mathrm{O}$ \\
\hline Content (wt\%) & 56.73 & 42.55 & 0.13 & 0.40 & 0.12 & 0.04 & 0.03 \\
\hline
\end{tabular}

dolomite are listed in Table 1, the main phases of calcined dolomite are $\mathrm{CaCO}_{3}, \mathrm{Ca}(\mathrm{OH})_{2}, \mathrm{MgO}, \mathrm{Mg}(\mathrm{OH})_{2}$, etc., the X-ray diffraction results of calcined dolomite are shown in Figure 2. Aluminum powder is produced from pure aluminum, and it contains more than $99.5 \mathrm{wt} \%$ aluminum element. Ferrosilicon powder is taken from Fugu County, Shaanxi Province in China, and silicon content in ferrosilicon powder is greater than $75 \mathrm{wt} \%$.

\subsection{Experimental procedure}

\subsubsection{Calcined dolomite reduced by ferrosilicon with additive of aluminum}

Calcined dolomite, ferrosilicon and aluminum powder were dried respectively at $105^{\circ} \mathrm{C}$, and then were weighed and mixed with each other according to the prescribed ratio. Then the mixture was pressed into $\varphi 1 \mathrm{~cm} \times 1.5 \mathrm{~cm}$ cylinder. The cylinder was placed in a graphite crucible and put it into a vacuum furnace. The temperature is raised when the vacuum degree in the furnace is less than $10 \mathrm{~Pa}$. The furnace temperature rises to the set temperature and keeps for $1 \mathrm{~h}$. Stop heating when the insulation is sufficient, and cool the material to room temperature with 


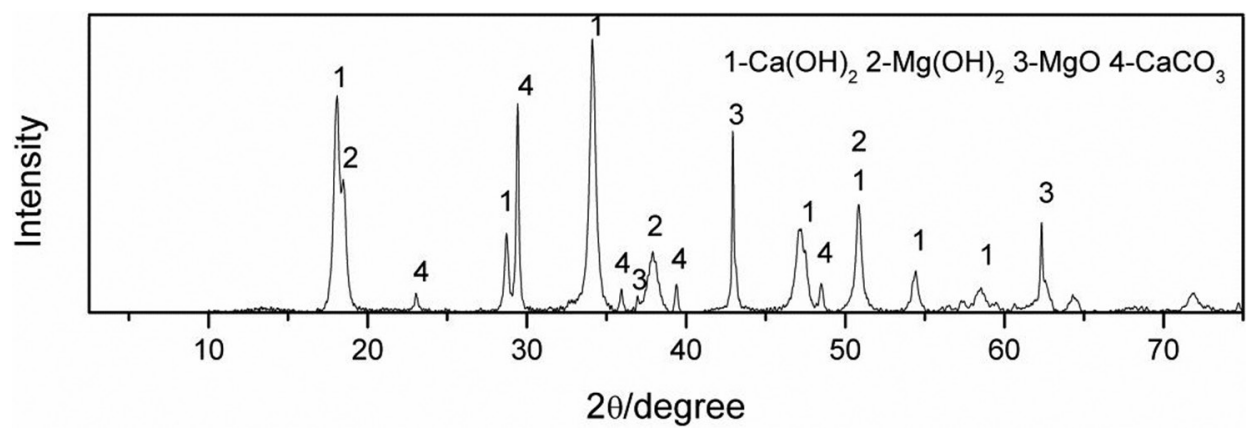

Figure 2: The X-ray diffraction results of calcined dolomite.

the furnace. The material was crushed and ground, and the X-Ray detected the phase composition of the material.

\subsubsection{Phase transformation of the mixture of aluminum and ferrosilicon during heating}

Mix ferrosilicon and aluminum powder in proportion and press the block. Other steps are the same as in Section 3.2.1.

\subsection{Experimental results and discussion}

\subsubsection{Calcined dolomite reduced by ferrosilicon with additive of aluminum}

According to the raw material ratio of the production process of magnesium smelting enterprises using silicon thermal method, the ratio of ingredients is calcined dolomite + ferrosilicon $=84 \mathrm{wt} \%+16 \mathrm{wt} \%$. The $2 \mathrm{wt} \%$ ferrosilicon was replaced by aluminum powder in present study, and the ratio of the ingredients in the reduction process is calcined dolomite + ferrosilicon + aluminum powder $=84 \mathrm{wt} \%+14 \mathrm{wt} \%+2 \mathrm{wt} \%$. The mixture is heated in a vacuum furnace at $700^{\circ} \mathrm{C}, 950^{\circ} \mathrm{C}$, $1200^{\circ} \mathrm{C}$, respectively. Then the slags were obtained after heating, respectively. The remaining materials are ground and examined by X-ray diffraction. The test results by X-Ray in the Figure 3.

It can be seen from Figure 3 that when heated to $700^{\circ} \mathrm{C}$, the main phases of the slag are $\mathrm{MgO}, \mathrm{Ca}(\mathrm{OH})_{2}$, $\mathrm{Ca}_{3} \mathrm{Al}_{2}(\mathrm{OH})_{12}, \mathrm{Mg}_{2} \mathrm{Al}_{4} \mathrm{Si}_{5} \mathrm{O}_{18}, \mathrm{FeSi}_{2}$, and Si. When heated to $950^{\circ} \mathrm{C}$. The phase composition of the material at $950^{\circ} \mathrm{C}$ is the same as that at $700^{\circ} \mathrm{C}$. When heated further to $1200^{\circ} \mathrm{C}$, the main phases of the slag are $\mathrm{Si}, \mathrm{FeSi}_{2}, \mathrm{MgO}, \mathrm{Ca}_{12} \mathrm{Al}_{14} \mathrm{O}_{33}$, and $\mathrm{Ca}_{2} \mathrm{SiO}_{4}$.

Compared with the main phases in calcined dolomite, when heated to $700^{\circ} \mathrm{C}, \mathrm{CaCO}_{3}, \mathrm{Mg}(\mathrm{OH})_{2}, \mathrm{Ca}(\mathrm{OH})_{2}$ and other decomposition reactions occurred in the calcined dolomite, and new aluminum-containing compounds such as $\mathrm{Mg}_{2} \mathrm{Al}_{4} \mathrm{Si}_{5} \mathrm{O}_{18}$ and $\mathrm{Ca}_{3} \mathrm{Al}_{2}(\mathrm{OH})_{12}$ were generated, indicating that aluminum has participated reactions in mixed materials. Aluminum compounds in the slag cannot be detected by X-ray diffraction due to low aluminum content. According to theoretical calculations, aluminum should participate in the reduction of magnesium oxide in the calcined dolomite at $950^{\circ} \mathrm{C}$. The diffraction peak of magnesium oxide weakened in the slag after heating to $1200^{\circ} \mathrm{C}$, and $\mathrm{Ca}_{12} \mathrm{Al}_{14} \mathrm{O}_{33}$ and $\mathrm{Ca}_{2} \mathrm{SiO}_{4}$ appeared in the slag, indicating that both aluminum and silicon participate in the reduction of magnesium oxide. Main phase in slag produced by reduction of magnesium oxide with ferrosilicon at $1200^{\circ} \mathrm{C}$ were $\mathrm{Ca}_{2} \mathrm{SiO}_{4}, \mathrm{Ca}_{12} \mathrm{Al}_{14} \mathrm{O}_{33}, \mathrm{FeSi}_{2}$, and $\mathrm{Si}$. The presence of $\mathrm{FeSi}_{2}$ and $\mathrm{Si}$ in the slag is mainly due to over-dosing during the reduction process. It can be seen that aluminum participates in the reduction reaction and generates a new phase comparing the main phase of the three slags. At $700^{\circ} \mathrm{C}$, aluminum and $\mathrm{MgO}, \mathrm{CaO}$, siliconcontaining compounds, etc. in calcined dolomite form $\mathrm{Ca}_{3} \mathrm{Al}_{2}(\mathrm{OH})_{12}$ and $\mathrm{Mg}_{2} \mathrm{Al}_{4} \mathrm{Si}_{5} \mathrm{O}_{18}$. Between $700^{\circ} \mathrm{C}$ and $950^{\circ} \mathrm{C}$, the phase form of aluminum in the mixed material does not change. At $1200^{\circ} \mathrm{C}$, aluminum eventually turns into $\mathrm{Ca}_{12} \mathrm{Al}_{14} \mathrm{O}_{33^{*}}$

\subsubsection{High temperature phase transition of aluminum and ferrosilicon mixture}

It is difficult to detect the phase transition of aluminum in the reducing slag, because it accounts for a small proportion of the ingredients of the reduced calcined dolomite. In order to explore the phase transition of mixture with aluminum powder and ferrosilicon powder during heating. The aluminum powder is mixed with ferrosilicon and pressed a cylinder, the mixture ratio is aluminum powder + ferrosilicon $=12.5 \mathrm{wt} \%+87.5 \mathrm{wt} \%$. 
The cylinder is heated and kept for $1 \mathrm{~h}$ at $700^{\circ} \mathrm{C}, 950^{\circ} \mathrm{C}$ and $1200^{\circ} \mathrm{C}$ in vacuum furnace at $10 \mathrm{~Pa}$, respectively. After heating, the heated product is detected by $\mathrm{X}$-Ray detection, and the detection result is shown in Figure 4.

It can be seen from Figure 4 that phase transition has occurred between ferrosilicon and aluminum powder at $700^{\circ} \mathrm{C}$. Extremely weak diffraction peaks of the aluminum phase, and a new phase of $\mathrm{Al}_{3} \mathrm{FeSi}_{2}$ was produced. The main phase in the product is $\mathrm{Si}$ and $\mathrm{Al}_{3} \mathrm{FeSi}_{2}$. The phase composition of the heated product is the same at $700^{\circ} \mathrm{C}$ and $950^{\circ} \mathrm{C}$. When the temperature is raised to $1200^{\circ} \mathrm{C}$, compared with $700^{\circ} \mathrm{C}$ and $950^{\circ} \mathrm{C}$, the diffraction peak of $\mathrm{Si}$ is weakened, the appearance of diffraction characteristic peak of $\mathrm{Al}_{4.5} \mathrm{FeSi}$ phase and the main phases in the product are $\mathrm{Si}, \mathrm{SiC}, \mathrm{Al}_{4.5} \mathrm{FeSi}$,

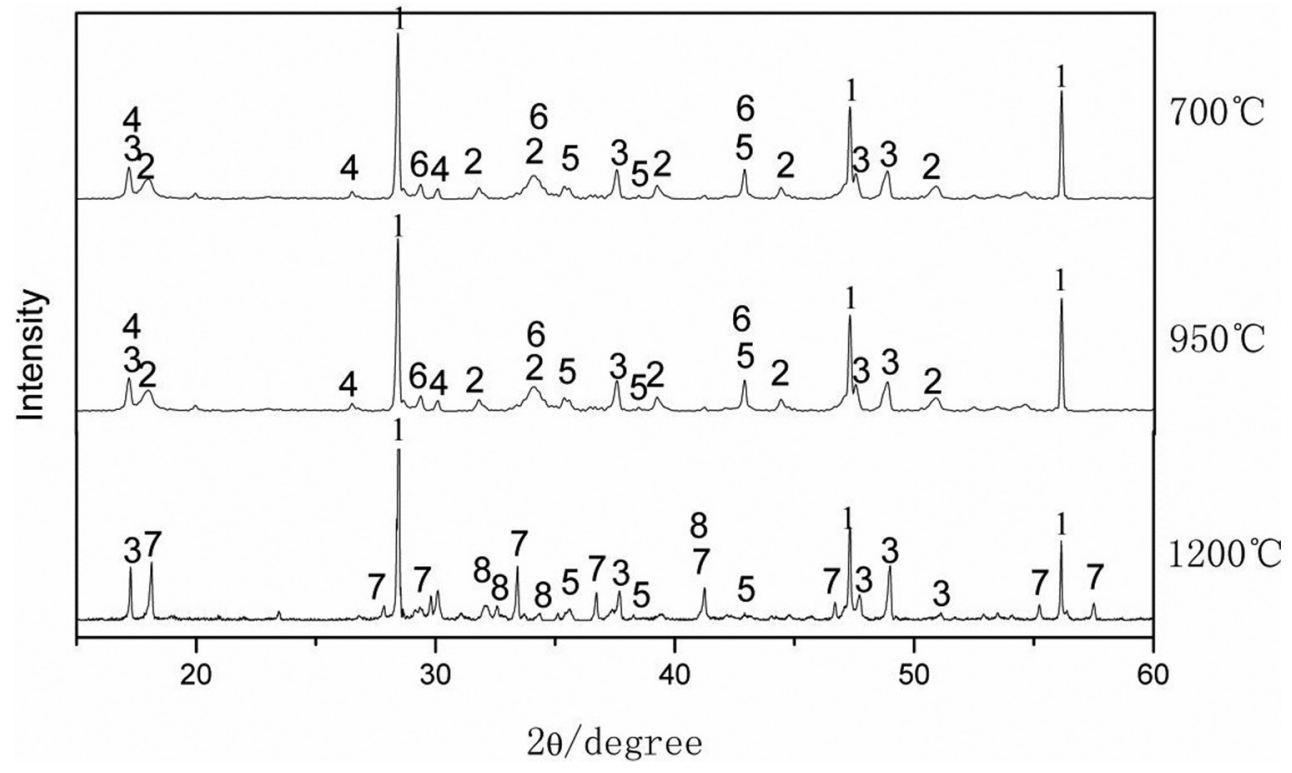

Figure 3: Slag phase at different temperatures.

$1-\mathrm{Si} ; 2-\mathrm{Ca}(\mathrm{OH})_{2} ; 3-\mathrm{FeSi}_{2} ; 4-\mathrm{Ca}_{3} \mathrm{Al}_{2}(\mathrm{OH})_{12} ; 5-\mathrm{MgO} ; 6-\mathrm{Mg}_{2} \mathrm{Al}_{4} \mathrm{Si}_{5} \mathrm{O}_{18} ; 7-\mathrm{Ca}_{12} \mathrm{Al}_{14} \mathrm{O}_{33} ; 8-\mathrm{Ca}_{2} \mathrm{SiO}_{4}$

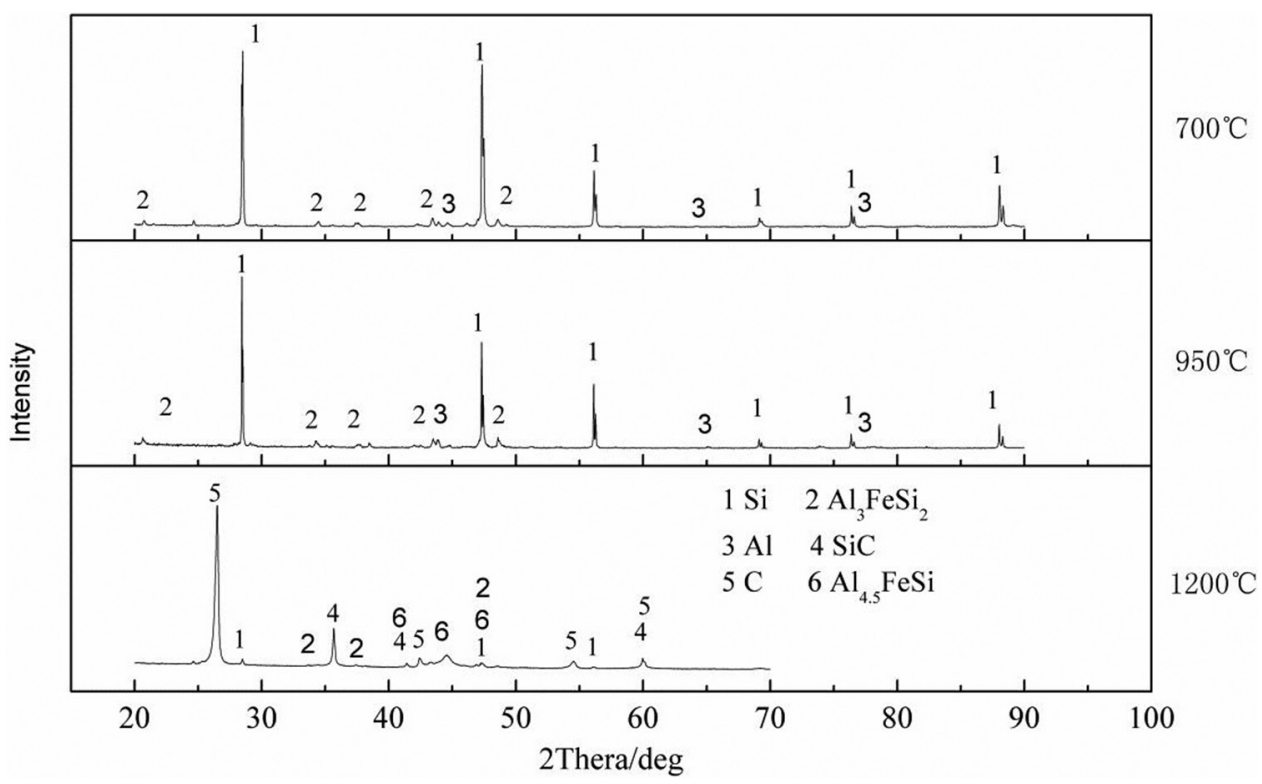

Figure 4: Heating phase diagram of 12.5 wt $\%$ aluminum powder and ferrosilicon mixture. 
$\mathrm{Al}_{3} \mathrm{FeSi}_{2}$, and $\mathrm{C}$. $\mathrm{C}$ comes from graphite crucible, and $\mathrm{SiC}$ is produced by the reaction between $\mathrm{Si}$ and carbon of graphite crucible. According to the change of diffraction peak intensity, it can be inferred that at $1200^{\circ} \mathrm{C}, \mathrm{Al}_{3} \mathrm{FeSi}_{2}$ phase has a trend of transition to $\mathrm{Al}_{4.5} \mathrm{FeSi}$ phases.

\subsubsection{Phase transformation difference of aluminum in two mixtures}

It can be seen from Figure 3 that in the process of heating up, the mixture of aluminum, calcined dolomite and ferrosilicon forms $\mathrm{Ca}_{3} \mathrm{Al}_{2}(\mathrm{OH})_{12}$ and $\mathrm{Mg}_{2} \mathrm{Al}_{4} \mathrm{Si}_{5} \mathrm{O}_{18}$ with the components in calcined dolomite, and finally forms $\mathrm{Ca}_{12} \mathrm{Al}_{14} \mathrm{O}_{33}$, while the main components of ferrosilicon, silicon and FeSi, do not react with aluminum obviously in the process of heating up. In the process of heating up the mixture of aluminum and ferrosilicon, aluminum and ferrosilicon first form $\mathrm{Al}_{3} \mathrm{FeSi}_{2}$ phase, and finally form $\mathrm{Al}_{4.5} \mathrm{FeSi}$ phases.

\section{Conclusions}

The reaction temperature and reaction products of mixture of aluminum and ferrosilicon in the reduction of magnesium oxide in calcined dolomite were studied by theoretical and experimental methods. The phase transition of mixture of aluminum and ferrosilicon in heating process and in production magnesium oxide were concluded that aluminum and ferrosilicon in the temperature rising process of magnesium oxide reduction, the following conclusions can be drawn:

1) In the reducing process of magnesium oxide by using a mixture of aluminum and ferrosilicon as a reducing agent, under the vacuum pressure of $10 \mathrm{~Pa}$ as the temperature rises, aluminum first reacts with magnesium oxide to form magnesium vapor and alumina, and simultaneously aluminum oxide and calcium oxide further form calcium aluminate above $720^{\circ} \mathrm{C}$. When the temperature reaches $1150^{\circ} \mathrm{C}$, silicon begins to participate in the reduction reaction of magnesium oxide, while silicon oxide and calcium oxide form calcium silicate. Magnesium oxide can be reduced by both aluminum and silicon when the temperature is above $1150^{\circ} \mathrm{C}$.

2) In the process of heating up, the mixture of aluminum, ferrosilicon and calcined dolomite forms $\mathrm{Mg}_{2} \mathrm{Al}_{4} \mathrm{Si}_{5} \mathrm{O}_{18}$ and $\mathrm{Ca}_{3} \mathrm{Al}_{2}(\mathrm{OH})_{12}$ phase with the components in calcined dolomite. $\mathrm{Mg}_{2} \mathrm{Al}_{4} \mathrm{Si}_{5} \mathrm{O}_{18}$ and $\mathrm{Ca}_{3} \mathrm{Al}_{2}(\mathrm{OH})_{12}$ phase finally form $\mathrm{Ca}_{12} \mathrm{Al}_{14} \mathrm{O}_{33}$ phase. The interaction between aluminum and ferrosilicon in the mixture is less; the mixture of aluminum and ferrosilicon first forms $\mathrm{Al}_{3} \mathrm{FeSi}_{2}$ phase, and finally has the trend of forming $\mathrm{Al}_{4.5} \mathrm{FeSi}$ phase. There is a great difference between the phase transformation of aluminum in the mixture of aluminum, ferrosilicon and calcined dolomite and that of aluminum in the mixture of aluminum and ferrosilicon.

Acknowledgements: This study was supported by the Shaanxi Provincial Department of Education special research project (18JK0480) and Shaanxi Provincial Natural Science Foundation Research Fund Project (2018JM5171) for the financial support of the project.

\section{References}

[1] Bugdayci M., Turan A., Alkan M., Yucel O., Effect of Reductant Type on the Metallothermic Magnesium Production Process. High Temp. Mater. Proc., 2018, 37(1), 1-8.

[2] Yang K., Chen Q., Ren J., Coupled heat transfer and chemical reactions in magnesium production retorts. Journal of Tsinghua University Science and Technology, 2009, 49(5), 755-758.

[3] Li R.B., Zhang S.J., Guo L.J., Wei J.J., Numerical study of magnesium $(\mathrm{Mg})$ production by the Pidgeon process: Impact of heat transfer on Mg reduction process. Int. J. Heat Mass Tran., 2013, 59, 328-337.

[4] Wang C., Zhang S., Guo L., Investigation on the effective thermal conductivity of typical Pidgeon process briquette with a combined model. Int. J. Heat Mass Tran., 2017, 115, 1348-1358.

[5] Gao F., Nie Z.-R., Wang Z.-H., Gong X.-Z., Zuo T.-Y., Assessing environmental impact of magnesium production using Pidgeon process in China. T. Nonferr. Metal. Soc., 2008, 18(3), 749-754.

[6] Li Y., Fan Y., Chen Z., Cheng F., Guo Y., Chemical, Mineralogical and Morphological Characteristics of Pidgeon Magnesium Slag. Environ. Eng. Sci., 2016, 33(4), 290-297.

[7] Morsi I.M., Ali H.H., Kinetics and mechanism of silicothermic reduction process of calcined dolomite in magnetherm reactor. Int. J. Miner. Process., 2014, 127, 37-43.

[8] Baek Y.-H., Lee B.-D., Lee K.-W., Han G.-S., Han J.-W., Study of the Thermal Reduction Behavior of Dolomite by the Pidgeon process. Korean J. Met. Mater., 2016, 54(2), 104-112.

[9] Zhang C., Chu H., Gu M., Zheng S., Experimental and numerical investigation of silicothermic reduction process with detailed 
chemical kinetics and thermal radiation. Appl. Therm. Eng., 2018, 135, 454-462.

[10] Fu D.-X., Feng N.-X., Wang Y.-W., Peng J.-P., Di Y.-Z., Kinetics of extracting magnesium from mixture of calcined magnesite and calcined dolomite by vacuum aluminothermic reduction. T. Nonferr. Metal. Soc., 2014, 24(3), 839-847.

[11] Wang Y., You J., Peng J., Di Y., Production of Magnesium by Vacuum Aluminothermic Reduction with Magnesium Aluminate Spinel as a By-Product. JOM-J. Min. Met. Mat. S., 2016, 68(6), 1728-1736.
[12] You J., Wang Y., Deng X., Liu K., Magnesium Extraction from Calcined Dolomite by Vacuum Thermal Reduction with SolidWaste of Al-Fe Alloy. Chin. J. Vac. Sci. Tech., 2016, 36(4), 436-441.

[13] Liu Z.-Q., Liu J.-X., Jiang B., Qiu Q., Process for Preparing Magnesium from Dolomite by Vacuum Aluminothermic Reduction. Nonferrous Metals, 2010, 02, 56-58.

[14] Wu X., Thermal reduction of $\mathrm{Mg}$ with reduction agent Al-Si-Fe ternary alloy. Nonferrous Metals, 2000, 52(2), 72-74, 97. 